Vol.15, No. 55, April, 2020, 584-593

\title{
PERFORMANCE ANALYSIS OF A DIESEL ENGINE OPERATED BY BIODIESEL BLENDS PREPARED FROM WASTE COOKING OIL
}

\author{
Bishoy Sobhy Gabrah*, Moustafa Fathy Abdelkhalek, Mahmoud Mohamed Kamal, \\ Mohamed Abdelhay and Adham Mohamed Abdelkader \\ Department of Mechanical Engineering- Faculty of Engineering, Ain Shams University. Cairo. Egypt. \\ *Corresponding author E-mail: gabrahbishoy@gmail.com.
}

\begin{abstract}
The Biodiesel was prepared from waste vegetable cooking oil that was collected from potato chips factory. It was prepared at the laboratories of faculty of Science Ain Shams University by transesterification method. The oil was filtered and heated, then methanol was added in the presence of potassium hydroxide as a catalyst. Several blends of biodiesel and mineral diesel were produced to be used in this study: B0, B10, B20 and B30 respectively. These blends were used to operate a single cylinder air cooled diesel engine of model: Deutz (F1L511) to analyze its performance and emissions. The thermal efficiency was improved when the blend B20 was used. The exhaust gases temperature increased by increasing the blending ratio. The carbon monoxide $(\mathrm{CO})$ emission was decreased by increasing the blending ratio. The nitrogen oxides (NOx) emissions were increased by using biodiesel blends. The best performance of the engine was obtained by using the blend B20.
\end{abstract}

\section{KEY WORDS: Waste Cooking Oil, Biodiesel, Performance Analysis, Compression Ignition Engines, Exhaust, Emissions.}

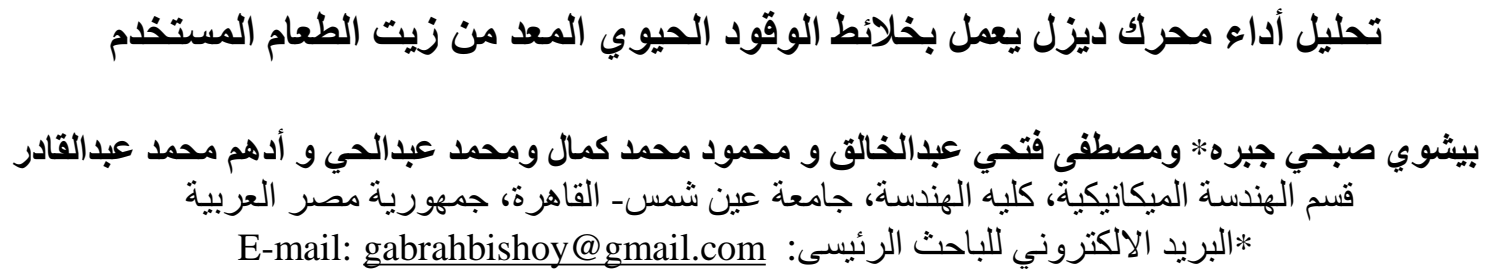

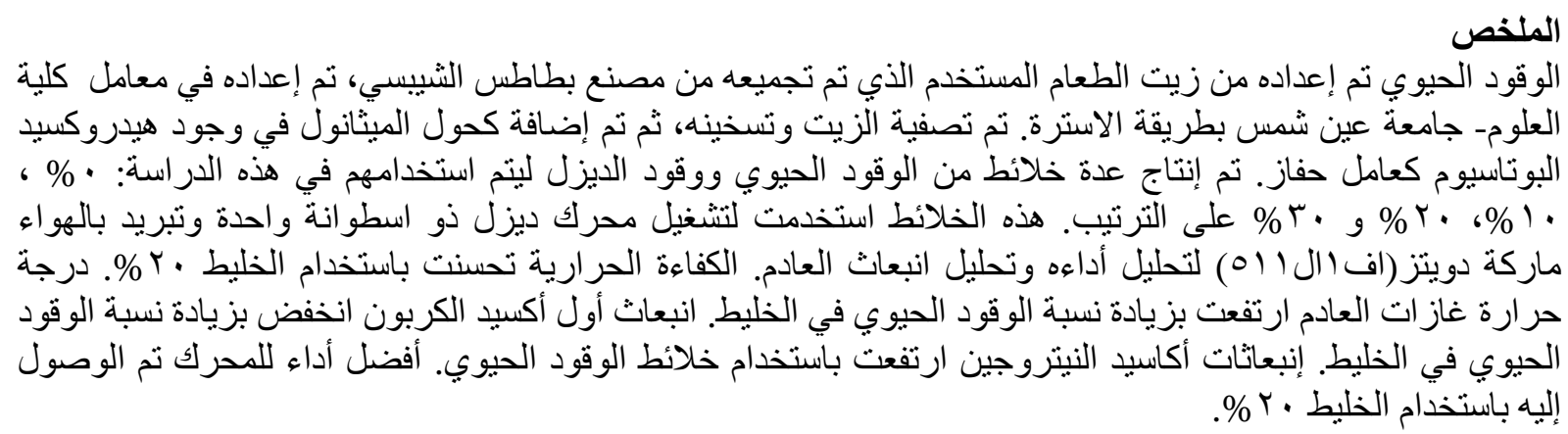

الكلمات المفتاحية: زيت الطعام المستخدم ، الوقود الحيوي ، تحليل الأداء ، محرك الديزل ، العادم ، الانبعاثات. 


\section{INTRODUCTION}

In the last few decades many researches were done to find alternatives fuel as it is expected that the fossil will run out about the year 2088 due to the increased consumption of fuel especially by the transportation sector [Elsolh N. 2011]. The quantity of produced petroleum had been decreased by the organization of the petroleum exporting countries (OPEC) to overcome this problem and the crisis that will appear and will affect our modern life style [Kahn J., Rang H., et al 2002]. The global concern in finding an alternative fuel lead to several trials to produce energy. Biodiesel was one of these alternative fuels. Biodiesel has many advantages as it is renewable, natural fuel, gives lower amount of harmful emissions and increases the efficiency of the engine [Elsolh N. 2011]. Biodiesel is used directly or blended with diesel. Biodiesel doesn't need any modification to be done into the engine. However, in minor cases some modifications may be done to the engine like altering the compression ratio, altering the injection pressure, using different types of oil in preparing biodiesel, etc. Biodiesel is prepared by trans-esterification method by which the oil passes with many stages like filtering the oil and heating it and adding alcohol and a catalyst as Sodium Hydroxide or Potassium Hydroxide. As a result, a fatty methyl ester is produced [Dorado P., et al 2003].

Many studies stated that biodiesel can be used directly as a fuel or by using it in the blended form with diesel to improve the performance of the engine and decreasing the harmful emissions that affect the environment [Kumar A., Dhar A., et al 2014]. The harmful emissions were reduced due to the amount of oxygen component in the chemical formula of biodiesel [EL-Kassaby M., et al 2013]. Biodiesel can be used safely up to 30\% without any modification for the engine, however, when using biodiesel only as a fuel minor modification may be required [Elsolh N. 2011 - EL-Kassaby M. 2013 - Nagarhalli V., Nandedkar M 2010]. Rudolf Diesel the inventor of the diesel engine said that the diesel engine can be run by straight vegetable oils, but practically some problems like bad quality of combustion and bad atomization may appear as a result of using vegetable oils directly in the engine as its viscosity is higher than that of diesel and biodiesel. Other problems that may appear are sticking of the cylinder and the piston and gumming as straight vegetable oils have heavier hydrocarbon chain [Nagarhalli M. V., Nandedkar V.M 2010]. However, preheating the oil the reduces the viscosity of the vegetable oil [Agarwal A., Rajmanoharan K. 2009].

Many studies were done to analyze the performance and exhaust emissions of diesel engines operated with different blends of biodiesel and diesel [Kalligeros S. 2003 - Kumar A. 2014 Ramalingam S. 2015 - EL-Kassaby M. 2013 - Patil S. 2012]. These studies concluded that the thermal efficiency increased and the brake specific fuel consumption (bsfc) decreased when biodiesel is used as a blend up to B20. On the other hand, regarding the exhaust emissions CO decreases and total hydrocarbon (THC) decreases, but NOx increases when biodiesel is used [Kalligeros S. 2003 - Kumar A. 2014 - Ramalingam S. 2015 - EL-Kassaby M. 2013 - Patil S. 2012 - Kalligeros S. 2003 - Raheman H. 2004].

[Kumar A., Kim W. 2014] investigated the performance of a compression ignition engine by using Karanja oil biodiesel blends with constant engine speed of $1500 \mathrm{rpm}$. They found that increasing the biodiesel percentage in the blend reduced the injection duration, and when they increased the injection pressure the injection duration is reduced and the peak injection rate is increased. When the biodiesel percentage in the blending is decreased, the characteristics of the fuel spray were changed as there were reduction in the Sauter mean diameter and arithmetic mean diameter of the droplets as a result of lower fuel viscosity and density. The thermal efficiency increased by using biodiesel, and increased also when the injection pressure was increased. As a result, for their study, they found that the performance of the engine was improved and there was a reduction in the harmful emissions when Karanja oil biodiesel blend B10 was used to operate the engine without any modification.

[Labeckas G. and Slavinskas S. 2006] analyzed the performance of a compression ignition engine operated by B5, B10, B20 and B35 blends of rapeseed oil methyl ester and mineral diesel. The NOx emissions increased when the engine speed and the biodiesel percentage in the blend were increased because of the increased mass amount of oxygen in the fuel. The CO emissions and the smoke were reduced, while carbon dioxide emissions, bsfc and the 
temperature of the exhaust gases were increased slightly for higher blends. There was a significant reduction in the unburned hydrocarbons for all the blends.

[El-kassaby M., et al 2013], investigated the effect of altering the compression ratio of a diesel engine operated by biodiesel blends. They found that bsfc increased by increasing the percentage of biodiesel in the blend. The bsfc decreased when the compression ratio was increased. They stated that using B20 gave close results to that resulting from using pure diesel at any compression ratio and speed. There was an improvement in the cylinder pressure and the performance of the engine when the compression ratio was increased. They also found that increasing the compression ratio gave better performance with biodiesel than that was given by mineral diesel.

[Ramalingam S. et al 2015] investigated the injection timing and compression ratio effect on the performance of a compression ignition engine by using B20 Annona methyl ester as the operating fuel. They also analyzed the combustion characteristics and the exhaust emissions of the engine. Their results showed that the performance was enhanced by altering the injection timing from $27^{\circ}$ to $30^{\circ} \mathrm{bTDC}$. They also found that the thermal efficiency was increased and the bsfc decreased by using biodiesel. Regarding the exhaust emissions, there was a significant reduction in $\mathrm{NOx}, \mathrm{CO}$ and $\mathrm{HC}$ emissions.

[Nagarhalli V. et al 2010] analyzed the emissions and the performance characteristics of a small single cylinder compression ignition engine operated with different blends of Karanja biodiesel and mineral diesel. They also studied the effect of changing the injection pressure to be: 190 bar, 200 bar and 210 bar respectively. They concluded that Karanja biodiesel could be used without any modifications to the engine. The best results obtained were by using B40 at injection pressure of 200 bar.

This study was done to analyze the performance of a diesel engine operated with different biodiesel blends and the results showed that biodiesel can be used safely as an alternative fuel and gave better performance in the case of the blend B20.

\section{MATERIALS AND METHODS}

The biodiesel used in this study was gathered from potato factories. It was prepared by transesterification method at the laboratories of Faculty of Science Ain Shams University. The oil was filtered by using a set of filters and a pump. Then it was heated to $90{ }^{\circ} \mathrm{C}$, after that methyl alcohol was added with a ratio of 1:10 in the presence of potassium hydroxide as a catalyst. The mixture was agitated by a magnetic agitator and it was left for 3 days to separate. After that the washing process was used to get pure biodiesel. The chemical analysis of the biodiesel is listed in Appendix 2. The test rig is shown in figure (1).

The engine used in this study is a Deutz F1L511 diesel generator engine of a single cylinder, four - stroke, air cooled and direct injection compression ignition engine. It has a displacement of $825 \mathrm{~cm}^{3}$, a stroke of $105 \mathrm{~mm}$ and a bore of $100 \mathrm{~mm}$. All the specifications of the engine are listed in Appendix 1. Biodiesel/ Diesel blends of B0, B10, B20 and B30 respectively, are used to analyse the performance of the engine, its combustion characteristics and the exhaust emission levels. The experiment is performed at a constant engine speed of $1500 \mathrm{rpm}$ and a constant compression ratio of 17 by loading the engine with different loads ranging from no load condition to full load. The load on the engine is measured by using a set of 6 heaters each of $1 \mathrm{KW}$, using a power variac transformer, voltmeter (accuracy of $\pm 3 \%$ ) and a current clamp (accuracy of $\pm 2 \%$ ), as shown in figure (2). The exhaust temperature and the intake air temperature are measured by using a $\mathrm{K}$ type thermocouple. The mass flow rate of the fuel is measured by putting the fuel tank on an electric balance and operating the engine for 15 minutes for every change in the load. The mass flow rate of the intake air is measured by using an air box (barrel with a flange in which an orifice of 1 inch is fixed to it), and a manometer that are connected to the intake manifold. The air to fuel ratio and the equivalence ratio are calculated for every blend at every load by using the stoichiometric combustion equations for every blend. A gas analyser device shown in figure (2), of Lano type and its model is Lancom series III (accuracy of $\pm 10 \mathrm{ppm}$ ) is used to measure the amount of carbon monoxide (ppm) and nitrogen oxides (ppm). 
PERFORMANCE ANALYSIS OF A DIESEL ENGINE OPERATED BY BIODIESEL BLENDS PREPARED FROM WASTE COOKING OIL

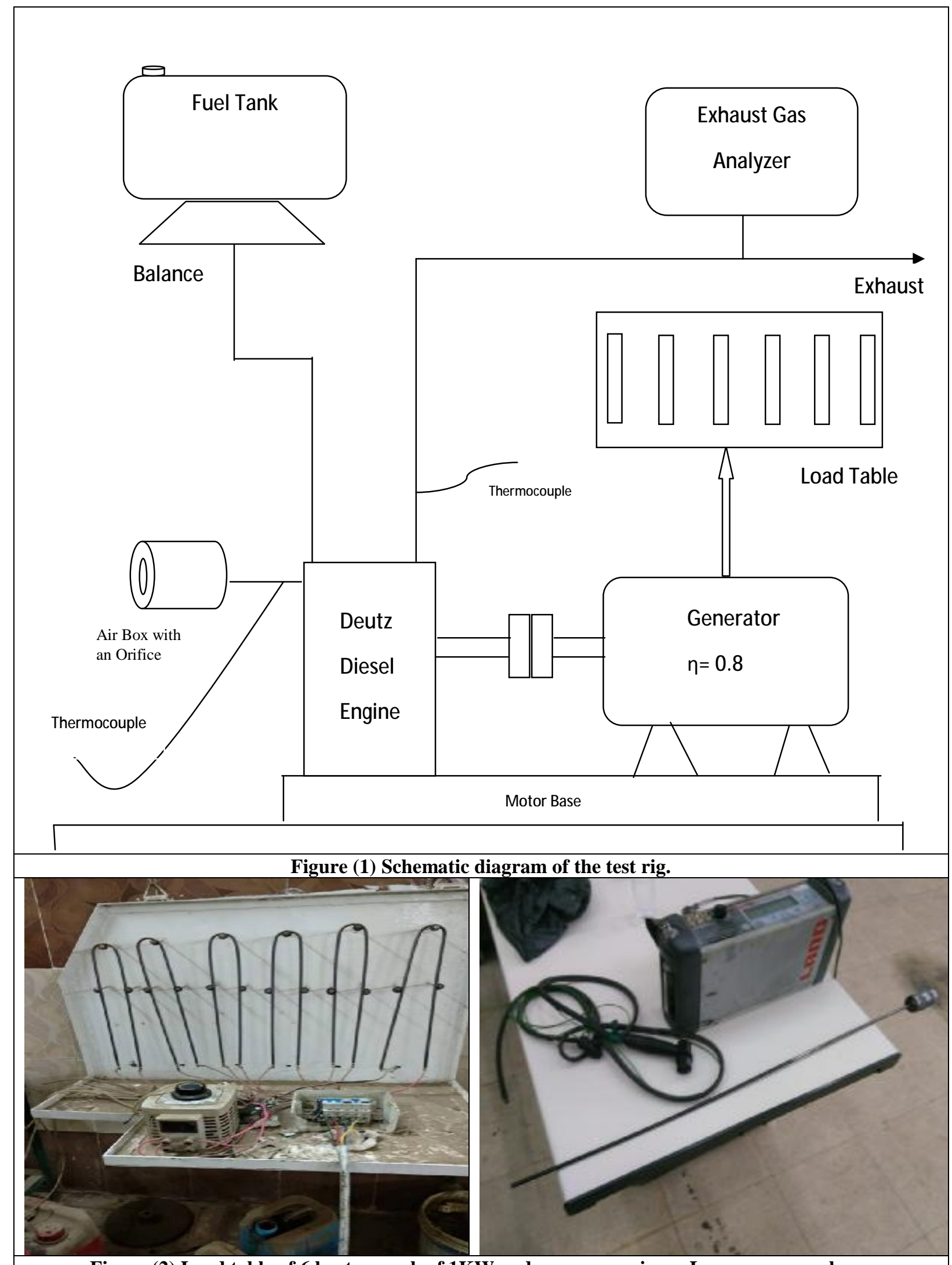

Figure (2) Load table of 6 heaters each of $1 \mathrm{KW}$ and a power variac. - Lancom gas analyzer 


\section{RESULTS AND DISCUSSION:}

\subsection{Engine Performance:}

\subsubsection{Brake Thermal Efficiency:}

Figure 3 shows the effect of the blend on brake thermal efficiency of Deutz F1L511 generator engine used in this study. The thermal efficiency as a function of load is shown for different blends. The brake thermal efficiency increased for the blend B20 than that of pure diesel due to the presence of higher amount of oxygen in B20 which in turn improved the combustion. The blend B30 has the lowest thermal efficiency. In general, all the biodiesel blends give acceptable performance and the thermal efficiency for all the blends are close to that of pure mineral diesel. The efficiency was improved by an average of $2.1 \%$ using the blend B20 than pure diesel. These results are close to that given by [El-kassaby M., et al 2013].

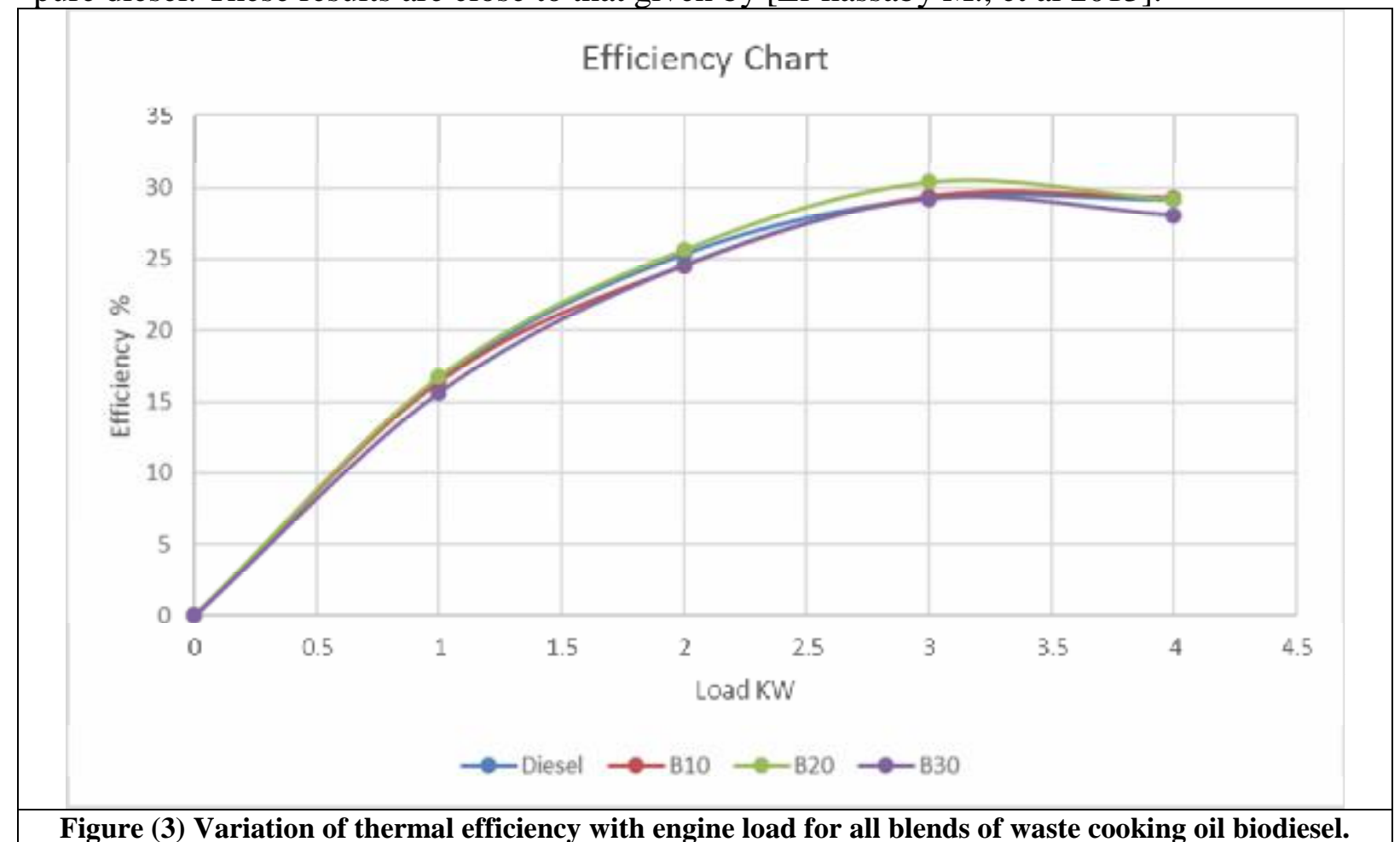

\subsubsection{Exhaust Gases Temperature:}

As shown from Figure 4, the exhaust temperature is plotted against the engine load for different blending ratios. The exhaust temperature increases for biodiesel blends B20 and B30 than pure diesel. The blend B10 exhaust temperatures are lower than that of pure diesel. This increase in exhaust temperature is due to the increase in the adiabatic flame temperature. Decreasing the heating value leads to decrease the exhaust temperature while decreasing the efficiency leads to increase the exhaust temperature [Hellier P. et al (2018)]. For B10 the effect of decreasing the heating value is dominant while in B 30. the effect of decreasing the efficiency is dominant. For B 20, increasing the exhaust temperature may be attributed to increase the percentage of excess oxygen and the long residence time of the biodiesel. 


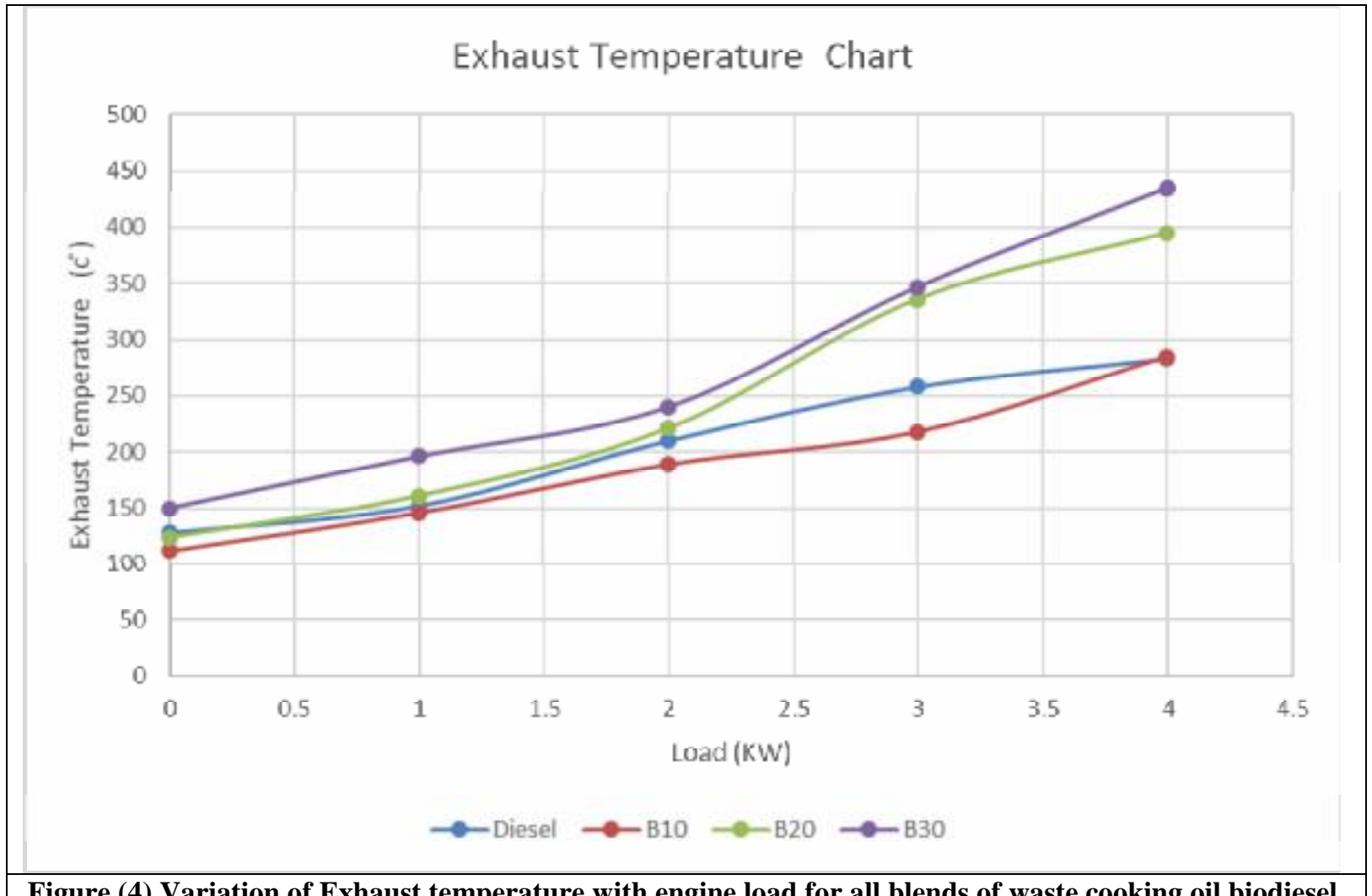

Figure (4) Variation of Exhaust temperature with engine load for all blends of waste cooking oil biodiesel.

\subsection{Emissions:}

\subsubsection{CO emission:}

As shown from Figure 5, $\mathrm{CO}$ emissions is plotted against the equivalence ratio for every load for every blending ratio. The equivalence ratio is calculated for every blend at every load using the stoichiometric combustion equations. The $\mathrm{CO}$ emissions decreases with using biodiesel blends B10, B20 and B30 respectively. The $\mathrm{CO}$ emissions decreases by increasing the biodiesel blending ratio. This is due to the presence of oxygen in the composition of biodiesel. The exhaust temperature depends mainly on the percentage of excess oxygen, the heating value and the efficiency. The decrease of $\mathrm{CO}$ emissions for blends with higher biodiesel concentration may be attributed to oxygenated nature of the biodiesel which leads to improve the combustion and reduce $\mathrm{CO}$ emissions. The higher cetane number may lead to reduce $\mathrm{CO}$ emissions due to the lower probability of rich combustion zone formation. 


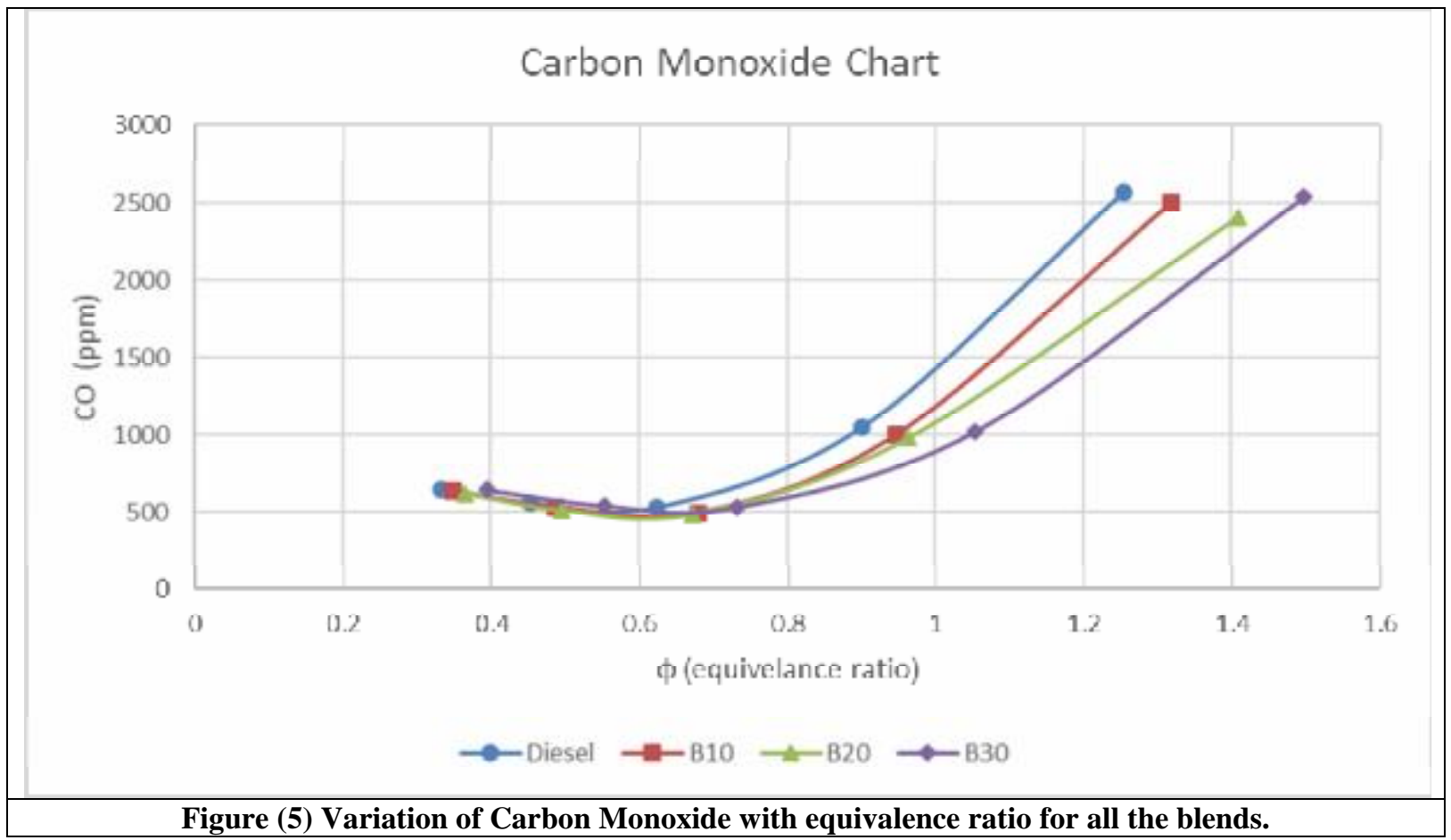

\subsubsection{NOx emissions:}

As shown from Figure 6 the NOx emissions are plotted against the equivalence ratio for every load at every blending ratio. The NOx emissions increase for the blends B0, B10, B20 and B30 respectively.

The increase in NOx emissions with biodiesel can be attributed to its higher adiabatic flame temperature due to its oxygenated nature which leads to more complete combustion, and the second reason is the heat radiated from soot produced in the flame zone which in turn reduces bulk flame temperatures by $25 \mathrm{~K}$ to $125 \mathrm{~K}$ according to the amount of soot produced at the engine different operating conditions, and the soot formation decreases by using biodiesel [Elsolh N. (2011)]. The NOx emission increase may be also formed due to the double bonded molecules contained in biodiesel than mineral diesel and these double bonded molecules have higher adiabatic flame temperature [Heywood, J. B. (1988)]. Double bonded molecules lead to increase the ignition duration delay for biodiesel combustion which result in increasing the residence time and increase the NOx emissions. 


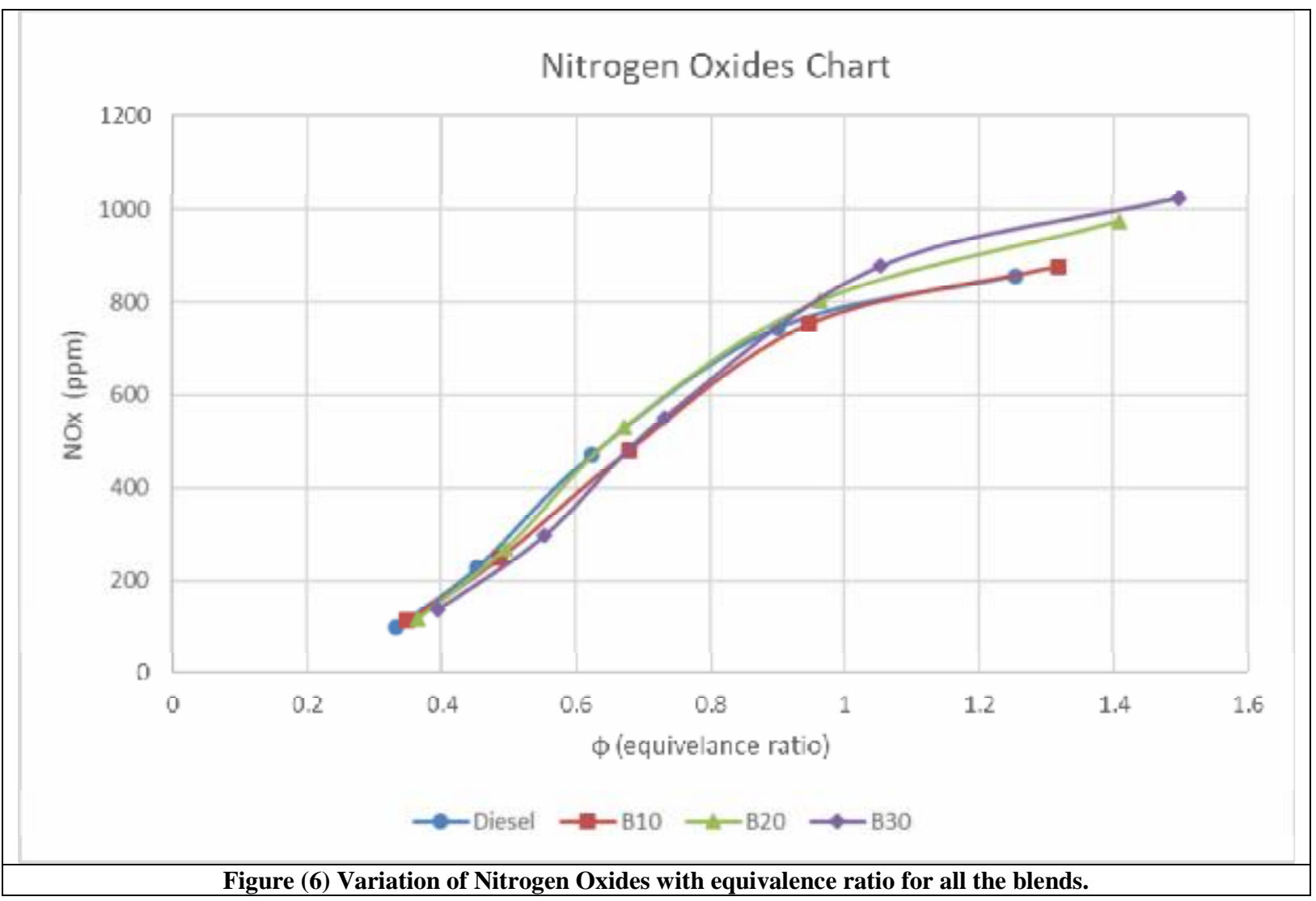

\section{CONCLUSION:}

The following main conclusions could be deduced from the course of the present study:

- Biodiesel blends up to $20 \%$ give optimum results for the performance and the emissions so close to that obtained by using mineral diesel at any injection pressure.

- The thermal efficiency of the engine is improved by using B20 than that of pure diesel.

- $\quad \mathrm{CO}$ emission decreases by using biodiesel blends than pure diesel.

- NOx emissions increase with using biodiesel blends.

- From this analysis using B20 for operating the engine give the optimum performance characteristics, it increased the efficiency and reduces the harmful emissions.

Table 1: Specifications of Deutz engine of model F1L511

\begin{tabular}{|l|c|}
\hline Model & F1L511 \\
\hline Cylinder number & 1 \\
\hline Chamber type & Direct injection \\
\hline Bore x stroke (mm) & $100 X 105$ \\
\hline Speed (r/min) & 1500 \\
\hline 15-minute output rating (kw/hp) & $6.8 / 9.2$ \\
\hline 12-hour output rating (kw/hp) & $5.7 / 7.7$ \\
\hline Maximum torque (N.m) & 44 \\
\hline Min. stable speed without load (r/min) & 900 \\
\hline Power/Rev [kw/(hp)/ rpm] & $5.7(7.7) / 1500$ \\
& $7.3(9.9) / 1800$ \\
\cline { 2 - 2 } & $\mathbf{8 . 2 ( 1 1 . 1 ) / 2 0 0 0}$ \\
\cline { 2 - 2 } & $\mathbf{9 . 7}(13.2) / 2500$ \\
\cline { 2 - 2 } & $10.5(14.3) / 2800$ \\
\cline { 2 - 2 } & $10.9(14.8) / 3000$ \\
\hline Cooling Method & Air-cooled \\
\hline Starting Manner & Hand crank or Electrical \\
\hline Net Weight $($ Kg) & 150 \\
\hline Gross Weight $($ Kg) & 180 \\
\hline Overall dimensions $(\mathbf{L} * W * H)(\mathbf{m m})$ & $437 * 530 * 671$ \\
\hline
\end{tabular}


Table 2: Chemical Analysis of Biodiesel produced from waste cooking oil.

\begin{tabular}{|l|c|}
\hline \multicolumn{1}{|c|}{ Fuel property } & Biodiesel (C17H34O2) \\
\hline Kinematic viscosity $\left(\mathrm{mm}^{2} / \mathbf{s}\right.$ at 313K) & 5.3 \\
\hline Density (Kg/ L, at 288K) & 0.897 \\
\hline Flash point (K) & 469 \\
\hline Pour point (K) & 262 \\
\hline Cetane number & 54 \\
\hline Ash content (\%) & 0.004 \\
\hline Sulfur content (\%) & 0.06 \\
\hline Water content (\%) & 0.4 \\
\hline Higher heating value (MJ/Kg) & 42.65 \\
\hline Free fatty acid (mg KOH/g oil) & 0.1 \\
\hline
\end{tabular}

\section{REFERENCES:}

1. Elsolh, N. (2011). The Manufacture of Biodiesel from Used Vegetable Oil. (Unpublished master's thesis). Kassel University, Hessen, Germany.

2. Kahn, J., Rang, H. \& Kriis, J. (2002) "Advance in Biodiesel Fuel Research." Proceedings of the Estonian Academy of Sciences Chemistry. 51(2) 75-117.

3. Dorado, M.P., Ballesteros, E., Arnal, J.M., Gómez, J. \& López, F.J. (2003). Exhaust Emissions from a Diesel Engine Fueled with Trans-esterified Waste Olive Oil. Elsevier - Fuel. 82 (11) 1311-1315.

4. Kumar, A. A., Dhar, A., Gupta, J.G., Kim, W., Choi, K., Lee, S., L., \& Park, S. (2014) "Effect of Fuel Injection Pressure and Injection Timing of Karanja Biodiesel Blends on Fuel Spray, Engine Performance, Emissions and Combustion Characteristics." Energy Conversion and Management. 91. 302-314.

5. EL-Kassaby, M. \& Nemitallah, A. M. (2013). Studying the Effect of Compression Ratio on an Engine Fueled with Waste Oil Produced Biodiesel/Diesel Fuel. Alexandria Engineering Journal. 52(1) 1-11.

6. Williams, B. J. (2002) "Production of biodiesel in Europe - The Markets." European. Journal of Lipid. Science and Technology 104. 361-362.

7. Ramalingam, S., Rajendran, S. \& Nattan, R. (2015) "Influence of Injection Timing and Compression Ratio on Performance, Emission and Combustion Characteristics of Annona Methyl Ester operated diesel engine." Alexandria Engineering journal 54 (3), 295-302.

8. Nagarhalli M. V., Nandedkar V.M., (2010) "Effect of injection pressure of emission and performance characteristics of karanja biodiesel and its blends on CI engine" International journal of applied engineering research 1 (4), 786.

9. Patil, S. \& Akarte, M. M. (2012) "Effect of Injection Pressure on CI Engine Performance Fueled with Biodiesel and its Blends." International Journal of Scientific and Engineering Research 3 (3), 2229-5518.

10. Agarwal, A., \& Rajamanoharan, K. (2009). "Experimental Investigations of Performance and Emissions of Karanja Oil and its Blends in a Single Cylinder Agricultural Diesel Engine.” Applied Energy. 86(1) 106-112.

11. Kalligeros, S., Zannikos, F., Stournas, S., Lois, E. \& Anastopoulos, G., Teas, C., \& Sakellaropoulos, F. (2003) "An Investigation of Using Biodiesel/Marine Diesel Blends on the Performance of a Stationary Diesel Engine." Biomass and Bioenergy 24 (2), 141-149.

12. Raheman, H., Phadatare, A. G. (2004) "Diesel Engine Emissions and Performance from Blends of Karanja Methyl Ester and Diesel." Biomass and Bioenergy 27 (4), 393397.

13. Labeckas, G. \& Slavinskas, S. (2006) "The Effect of Rapeseed Oil Methyl Ester on Direct Injection Diesel Engine Performance and Exhaust Emissions." Energy Conversion and management 47 (13-14), 1954-1967. 
14. Schumacher, L. G., Borgelt, S. C., Fosseen, D., Goetz, W. \& Hires, W. G. (1996) "Heavy-duty Engine Exhaust Emission Tests Using Methyl Ester Soybean Oil/Diesel Fuel Blends.” Bio-resource Technology 57 (1) 31-36.

15. Raheman, H., \& Ghadge, S. V. (2008) "Performance of Diesel Engine with Biodiesel at Varying Compression Ratio and Ignition Timing", Fuel 87 (12), 2659-2666.

16. Heywood, J. B. (1988). "Internal Combustion Engine Fundamentals" New York, McGraw-Hill Inc.

17. Hellier P., Talibi M., Eveleigh A. \& Ladommatos N. (2018) "An Overview of the Effects of Fuel Molecular Structure on the Combustion and Emissions Characteristics of Compression Ignition Engines.” Automobile Engineering vol. 232 (1) 90-105. 